\title{
Pękanie gorące złączy spawanych - badania i symulacje numeryczne
}

\section{Hot welds cracking - research and numerical simulations}

\section{Streszczenie}

W artykule przedstawione zostały prace nad opracowaniem metod obliczeniowych pozwalających określać skłonność złączy spawanych do pękania gorącego przy zastosowaniu analiz numerycznych procesów spawania metodą elementów skończonych. Opisane metody obliczeniowe opracowane zostały w oparciu o stosowane z powodzeniem od dłuższego czasu w przemysłowych aplikacjach narzędzie obliczeniowe, jakim jest SYSWELD. Zestawione ze sobą zostały wyniki rzeczywistych prób Houldcrofta, jak i analiz numerycznych tych przypadków. Zasygnalizowano również konieczność dalszego prowadzenia prac nad rozwojem tego ciekawego, a zarazem potrzebnego obszaru wiedzy, który jesteśmy w stanie rozwiązać również za pomocą analiz numerycznych.

Słowa kluczowe: MES; analizy numeryczne; pękanie gorące; Sysweld; Houldcroft test; BTR

\begin{abstract}
In this paper, works on the new calculation methods development for welds hot cracking prediction using Finite Element Method numerical analyses of welding processes were presented. Described calculation methods are based on a modern FEM software SYSWELD which has been successfully used for a long time in industrial applications. Results from the real Houldcroft welding tests and numerical analyses were compared. It was also notified that this very interesting and necessary knowledge area, which we can solve with FEM calculations and which need to be still developed.
\end{abstract}

Keywords: FEM; numerical analyses; hot cracking; Sysweld; Houldcroft test; BTR

\section{Wstęp}

Analizy numeryczne spawalniczych procesów wytwarzania służą obecnie zwykle optymalizacji oraz walidacji tych procesów, tak z punktu widzenia technologicznego, jak i w niektórych przypadkach w celu modyfikacji samej konstrukcji spawanej. Symulacje procesów spawania można podzielić na trzy podstawowe grupy różniące się obszarem analizy, ale i wynikami, które otrzymujemy. Są to:

- lokalne analizy numeryczne procesu spawania,

- globalne analizy numeryczne procesu spawania,

- predykcja pękania i zmęczenia złączy spawanych - połączona z analizą spawania i stanów krytycznych.

Ta ostatnia jest szczególnie złożonym obszarem i prowadzona jest zwykle na podstawie obliczeń stanu naprężeń konstrukcji bez uwzględnienia wpływu cyklu cieplnego procesu spawania, dodając następnie współczynniki bezpieczeństwa. Taka metodyka obliczeń w wielu przypadkach prowadzi do uzyskania bardzo niedokładnych wyników analiz. Dzięki ciągłemu rozwojowi oprogramowania do analiz numerycznych istnieje już obecnie możliwość prowadzenia lokalnych analiz spawania, a następnie na podstawie otrzymanych obliczeń niejednorodnego rozkładu struktur i własności materiałowych, naprężeń i odkształceń plastycznych, obciążenia analizowanej konstrukcji obciążeniami zewnętrznymi. $\mathrm{Na}$ podstawie otrzymanych wyników istnieje możliwość określenia uszkodzeń zmęczeniowych analizowanych konstrukcji spawanych.

W ostatnim czasie coraz więcej konstrukcji spawanych powstaje z różnego rodzaju stopów aluminium (szczególnie w transporcie i lotnictwie), nadstopów niklu (energetyka, lotnictwo) oraz stali nierdzewnych (energetyka, przemysł spożywczy, a także częściowo transport naziemny). Materiały te mimo swoich niewątpliwych zalet posiadają też wady. Jedną z najważniejszych jest wysoka skłonność do pękania gorącego. W przypadku materiałów typu inconel czy austenityczne stale nierdzewne, zjawisko to występuje zwykle w trakcie napraw technologiami spawalniczymi, ale również przy spawaniu produkcyjnym.

Z przeprowadzonych do tej pory badań i analiz wynika, że istnieje już możliwość obliczania pęknięć krystalizacyjnych w zakresie temperatur kruchości. Analizy tego zagadnienia przy pomocy metody elementów skończonych, składa się z analizy odkształceń, a następnie naprężeń szczątkowych.

Dr inż. Tomasz Kik - Politechnika Śląska, dr inż. Marek Slováček - MECAS ESI, doc. dr inż. Jaromír Moravec - TUL.

Autor korespondencyjny/Corresponding author. tomasz.kik@polsl.pl 
Odkształcenia związane są z powstawaniem pól temperatury w trakcie spawania tzn. że istnieje możliwość określenia obszaru powstania wady na podstawie lokalnego rozkładu odkształceń plastycznych lub lokalnych naprężeń szczątkowych. Wpływu składu chemicznego na pękanie na razie nie można określić za pomocą analiz numerycznych.

Aby możliwe było przeprowadzenie analiz powstawania pęknięć gorących, przeprowadzone zostały następujące badania:

- wyznaczenie potrzebnych danych materiałowych,

- przeprowadzenie prób spawalniczych,

- przeprowadzenie analiz numerycznych.

Część badań z tego zakresu przedstawiono w poniższej pracy.

\section{Ocena skłonności do pękania gorącego}

Pęknięcia gorące powstają w złączach spawanych w trakcie ich spawania. Zjawisko pękania gorącego jest głównie związane z wystąpieniem fazy ciekłej w mikrostrukturze. Faza ta jest obecna w obszarze spoiny przy jej krystalizacji oraz obszarze linii wtopienia, ale również w nagrzanych do wysokich temperatur obszarach strefy wpływu ciepła. Dodatkowo cienkie warstewki ciekłego metalu mogą występować w temperaturach znacznie niższych niż temperatura solidus danego stopu. Ze względu na segregację składników stopowych oraz występowanie zanieczyszczeń, zakres interwały temperatur krzepnięcia znacznie się rozszerza.

Z punktu widzenia występowania pęknięć gorących można je podzielić na:

- pęknięcia krystalizacyjne, które powstają w czasie krzepnięcia spoin;

- pęknięcia likwacyjne występujące w SWC (dokładniej zarówno w części obejmującej materiał rodzimy, jak i częściowo przetopionej), ale również występujące przy spawaniu wielowarstwowym, wynikające z ponownego nagrzewania wcześniej wykonanych ściegów;

- pęknięcia poligonizacyjne - powstające w trakcie spawania w wyniku spadku wytrzymałość w wysokich temperaturach. Podobnie jak krystalizacyjne, mogą one występować zarówno w SWC, jak i w materiale rodzimym oraz przy spawaniu wielowarstwowym.

W ujęciu ogólnym, pęknięcia gorące definiuje się jako rozdzielenie materiału po granicach ziaren, do którego dochodzi przy wysokich temperaturach, gdy poziom naprężeń i szybkość deformacji przekracza pewną wartość. Stygnięcie złącza spawanego powoduje powstanie naprężeń rozciągających, a co za tym idzie również odkształceń plastycznych. Jeżeli zdolność do tych odkształceń jest w danych obszarze niska, dochodzi do wyczerpania możliwości plastycznego odkształcania się materiału i wystąpienia pęknięcia.

Badania skłonności do pękania gorącego materiałów metalowych można rozdzielić wg różnych kryteriów i przykładowo mogą to być próby:

- znormalizowane,

- nieznormalizowane.

Według sposobu wymuszenia usztywnienia w obszarze złącza:

- próby z tzw. własnym usztywnieniem,

- próby z wymuszonym usztywnieniem (m.in. próba „Varestraint" i "Transvarestraint").

Według sposobu „obciążenia materiału":

- próby z rzeczywistym cyklem cieplnym,

- próby z symulowanym cyklem cieplnym od procesu spawania.
Jak już wspomniano na wstępie, prowadzone są już analizy numeryczne pękania gorącego w obszarze zakresu temperatur kruchości tzw. BTR (ang. Brittle Temperature Range). Pęknięcia krystalizacyjne powstają w końcowej fazie krystalizacji przy temperaturach nieznacznie ponad temperaturą solidus i pojawiają się na granicach ziaren, gdzie występuje cienka warstewka cieczy zamknięta w oddzielnych obszarach (rys. 1). Pokrywają się one z obszarem zakresu temperatur kruchości BTR charakteryzującymi się niemal zerowymi wartościami wydłużenia.
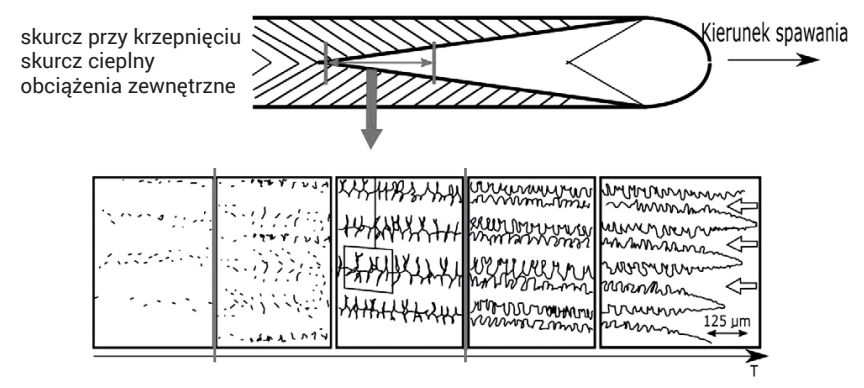

wysoka BTR - Brittle Temperature Range obieg cieczy

ciągliwość niska ciągliwość -> pękanie gorące

Rys. 1. Schemat powstawania pęknięć gorących

Fig. 1. Hot cracks creation scheme

W celu określenia stanu granicznego konieczne jest śledzenie wartości całkowitego odkształcenia plastycznego w obszarze BTR. W programie SYSWELD został określony parametr "cumulative plastic strains in BTR", jak również w danych wejściowych podane zostaną przedziały temperatur BTR wyznaczone eksperymentalnie. W dalszych pracach określone zostaną również zerowe wartości wytrzymałości i wydłużenia w zakresie BTR.

Obok wspomnianych badań, istotną częścią prac jest prowadzenie badań pękania gorącego w trakcie spawania. W tym celu wybrana została próba nazywana próbą Houldcrofta w warunkach zmiennej sztywności złącza (rys. 2).

Próba ta może być przeprowadzona przy użyciu metody TIG, jak również MIG (z jednym warunkiem: próbki dla każdej z metod różnią się wymiarami (rys. 2). Jednakże w literaturze można znaleźć informacje, że rozmiary tych próbek nie są wiążące i mogą być modyfikowane. Kształt próbki do testu Houldcrofta ma kształt "choinki” ze zmienną sztywnością tzn. zakłada się, że pęknięcie miałoby powstać od razu na początku w miejscu maksymalnej sztywności i zaniknąć w obszarze gdzie jest ona już znacznie niższa (wartości lokalnych odkształceń plastycznych oraz naprężeń szczątkowych zmieniają się wzdłuż próbki wraz ze zmieniającą się sztywnością próbki).

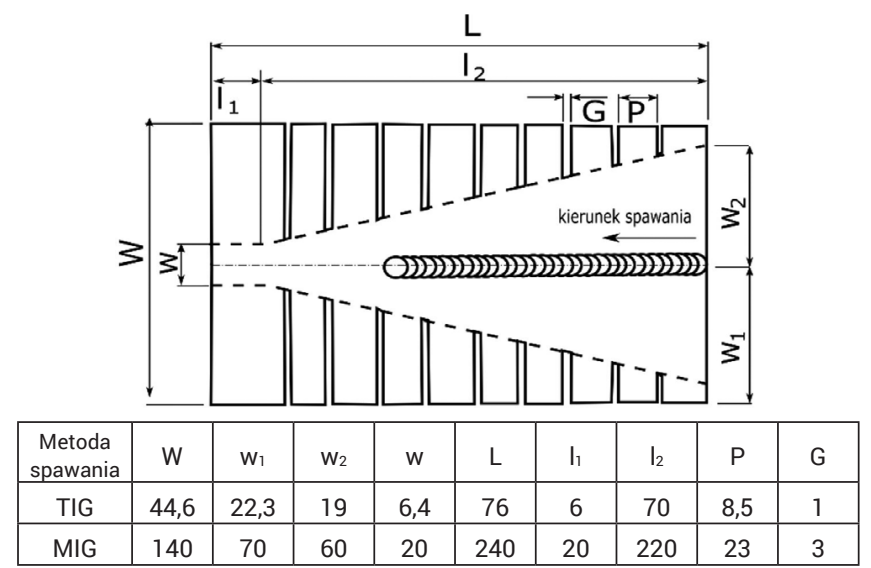

Rys. 2. Wymiary i kształt próbki do próby Houldcrofta

Fig. 2. Dimensions and geometry of Houldcroft's test specimen 


\section{Próby spawania}

Próby pękania gorącego wg założeń próby Houldcrofta przeprowadzono metodą MIG na próbkach ze stopu aluminium gatunku AW-6082 o grubości $2 \mathrm{~mm}$ z materiałem dodatkowym w postaci drutu litego AlMg4.5MnZr (5087) o średnicy $1,2 \mathrm{~mm}$. Po ustaleniu zakresu parametrów eksperymentu, przeprowadzono próby spawania w specjalnie przygotowanym przyrządzie pozwalającym na zamocowanie próbek w taki sposób, aby w trakcie spawania nie odkształcały się zbyt intensywnie (rys. 3).

Ponieważ przeprowadzone próby wykazały, że prawdopodobnie dla zastosowanej grubości blach wynoszącej 2,0 mm nie istnieje możliwość wytworzenia warunków sprzyjających zainicjowaniu pękania gorącego, próby powtórzono również na próbkach o grubości 4,0 mm. Również w tym przypadku nie zaobserwowano pęknięć, mimo że próby prowadzone były na próbkach „pełnych” tzn. bez nacięć (z tzw. pełną sztywnością materiału).

Ze względu na niepowodzenia w testach prowadzonych metodą MIG, wykonano również próby przetapiania metodą TIG. Próbki o grubości 2,0 mm zostały przetopione w wybranym zakresie parametrów dla obu wielkości próbek zalecanych w wytycznych próby Houldcrofta (rys. 4). W wyniku przeprowadzonych badań uzyskano pęknięcia gorące, których rozmiary stanowiły dane wejściowe do przeprowadzonych następnie analiz numerycznych.

Próby pękania gorącego wg założeń próby Houldcrofta przeprowadzono metodą TIG również dla próbek z nadstopu niklu INCONEL 625 o grubości 1,0 mm. Pękanie gorące zauważono po przekroczeniu wartości natężenia prądu ok. $45 \mathrm{~A}$ przy prędkości przetapiania równej 0,3 m/min (rys. 5).

\section{Analizy numeryczne}

Po uzyskaniu wyników z rzeczywistych prób spawania, podjęto próby przeprowadzenia analiz numerycznych w celu określenia metodologii prowadzenia obliczeń w zakresie określania skłonności do powstawania pęknięć gorących.
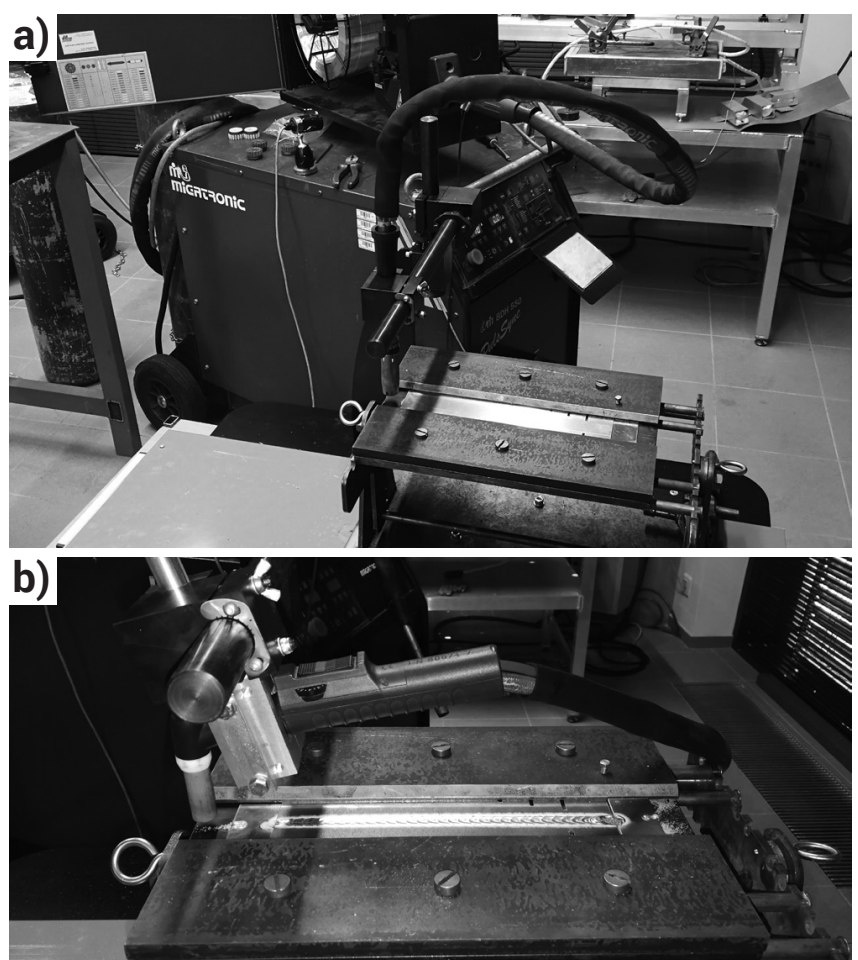

Rys. 3. Stanowiska do spawania próbek do próby Houldcrofta: a) MIG, b) TIG

Fig. 3. Experimental stand for Houldcroft tests welding: a) MIG, b) TIG
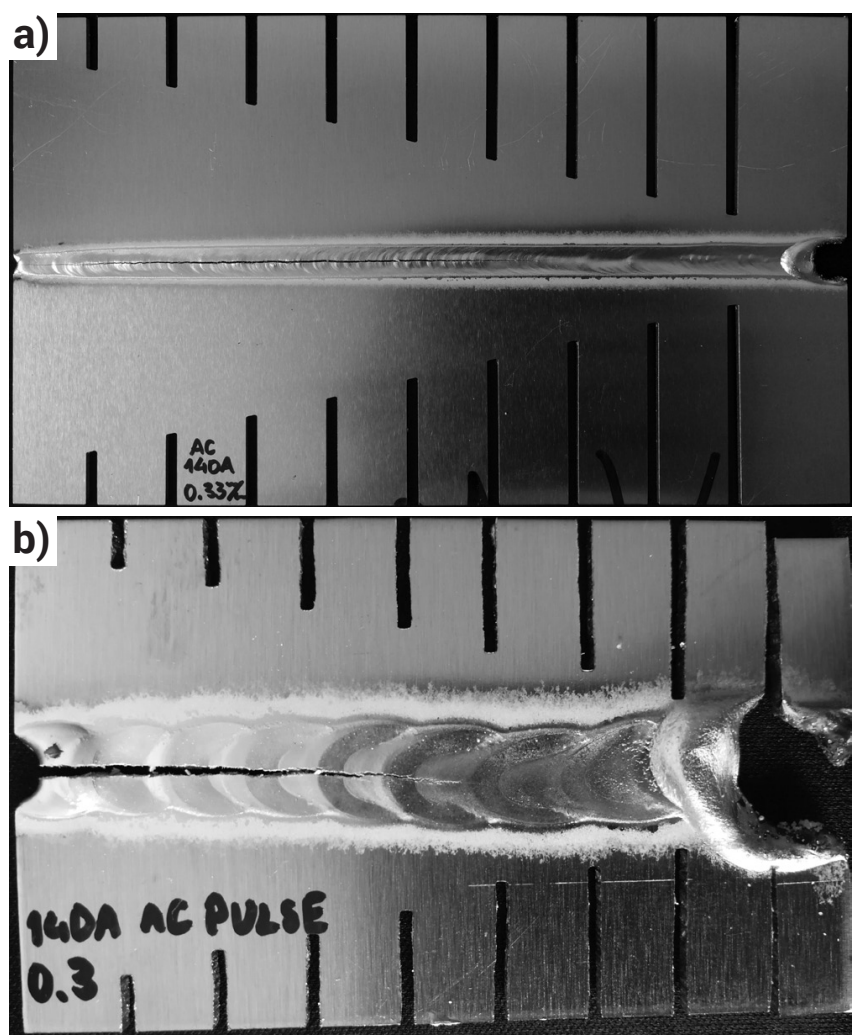

Rys. 4. Widok próbek ze stopu AW-6082 o grubości 2,0 mm w próbie Houldcrofta: a) próbka - natężenie prądu: 140 A AC, prędkość spawania: 0,33 $\mathrm{m} / \mathrm{min}, \mathrm{b})$ próbka - natężenie prądu: 140 A AC PULSE, prędkość spawania: $0,3 \mathrm{~m} / \mathrm{min}$

Fig. 4. View of $2,0 \mathrm{~mm}$ thickness $A W-6082$ aluminium alloy Houldcroft specimens: a) specimen - welding current: 140 A AC, welding speed: 0,33 $\mathrm{m} / \mathrm{min}, \mathrm{b})$ specimen - welding current: 140 A AC PULSE, welding speed: $0,3 \mathrm{~m} / \mathrm{min}$
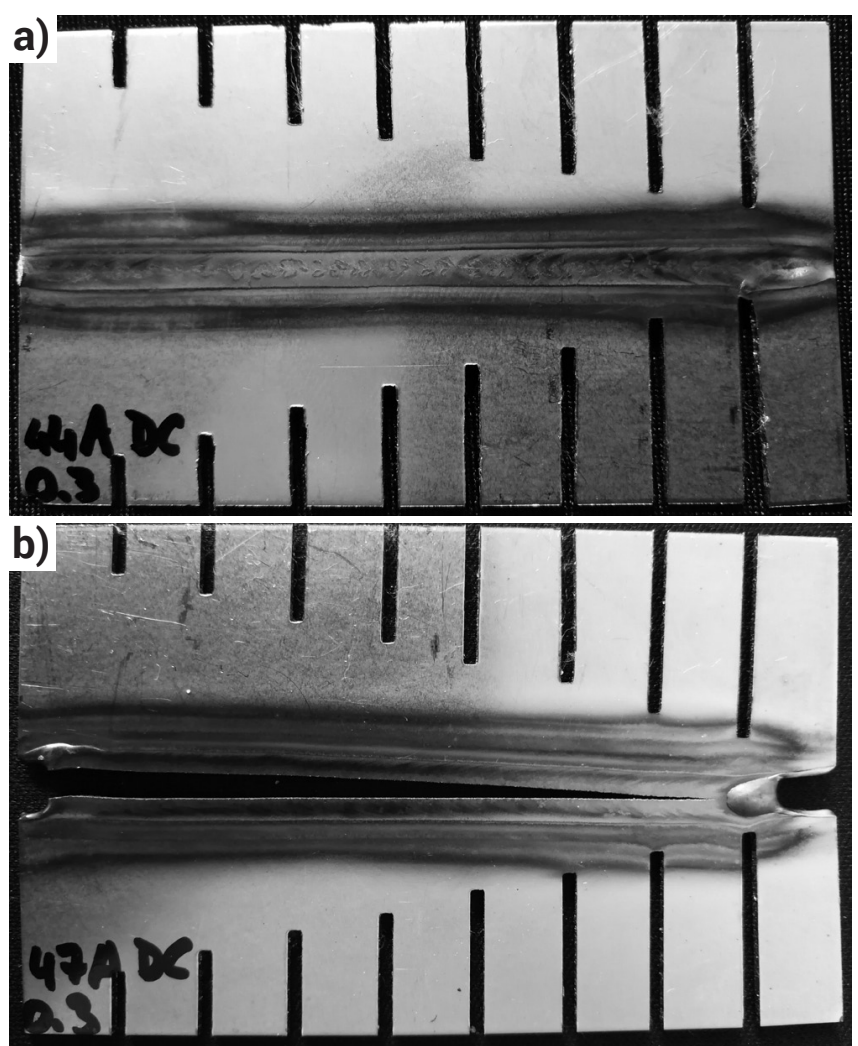

Rys. 5. Widok próbek ze stopu INCONEL 625 o grubości 1,0 mm w próbie Houldcrofta: a) próbka - natężenie prądu: $44 \mathrm{~A}$, prędkość spawania: 0,3 $\mathrm{m} / \mathrm{min}$, b) próbka - natężenie prądu: $47 \mathrm{~A}$, prędkość spawania: $0,3 \mathrm{~m} / \mathrm{min}$

Fig. 5. View of 1,0 mm thickness INCONEL 625 alloy Houldcroft specimens: a) specimen - welding current: $44 \mathrm{~A}$, welding speed: $0,3 \mathrm{~m} / \mathrm{min}$, b) specimen - welding current: $47 \mathrm{~A}$, welding speed: $0,3 \mathrm{~m} / \mathrm{min}$ 
Jako pierwsze, przeprowadzone zostały analizy numeryczne procesu spawania próbek ze stopu aluminium AW 6082 metodą MIG. Niestety, ponieważ nie doszło do powstania pęknięć, niemożliwym było również określenie wartości dopuszczalnych. Jednakże przeprowadzone eksperymenty były wystarczające, aby uzyskać pierwsze doświadczenia w zakresie analiz numerycznych.

Analizie poddano dwa warianty energii liniowej: $320 \mathrm{~J} / \mathrm{mm}$ oraz $400 \mathrm{~J} / \mathrm{mm}$. Na podstawie analizy pierwszych wyników analiz numerycznych, stwierdzono wyższe wartości naprężeń na początku próbki, czyli w miejscu, gdzie sztywność próbki jest większa (rys. 6).

Jedynie informacyjne zostały określone również wartości odkształcenia plastycznego w obszarze BTR (zakres BTR w tym przypadku został określony w przedziale $500 \div 600^{\circ} \mathrm{C}$ ). Wartości te zatem są jedynie orientacyjne, dodatkowo w analizowanych przypadkach nie powstały pęknięcia gorące w czasie rzeczywistych prób, stąd obliczone wartości odkształcenia plastycznego w obszarze BTR nie powinny wskazywać miejsc powstawania pęknięć gorących (rys. 7). Jak widać, wartości maksymalne są podobne, różni się tylko ich rozłożenie i natężenie występowania.

W przypadku badań z wykorzystaniem metody TIG użyte zostały mniejsze próbki wg wytycznych próby Houldcrofta. W tym celu konieczne było wykonanie nowego modelu obliczeniowego. Aby możliwe było przyspieszenie analiz numerycznych poprzez skrócenie czasu obliczeń, model numeryczny został wykonany jak połowa elementu rzeczywistego, a odpowiednio założone warunki brzegowe dotyczące symetrii pozwoliły na zachowanie pełnej zgodności z rzeczywistością (rys. 8 i 9). Było to możliwe, ponieważ zarówno model, jak i obciążenie cieplnej jest w tym przypadku symetryczne.

Pole temperaturowe $w$ tym przypadku jest wyraźnie szersze niż w przypadku spawania metodą MIG (rys. 8).
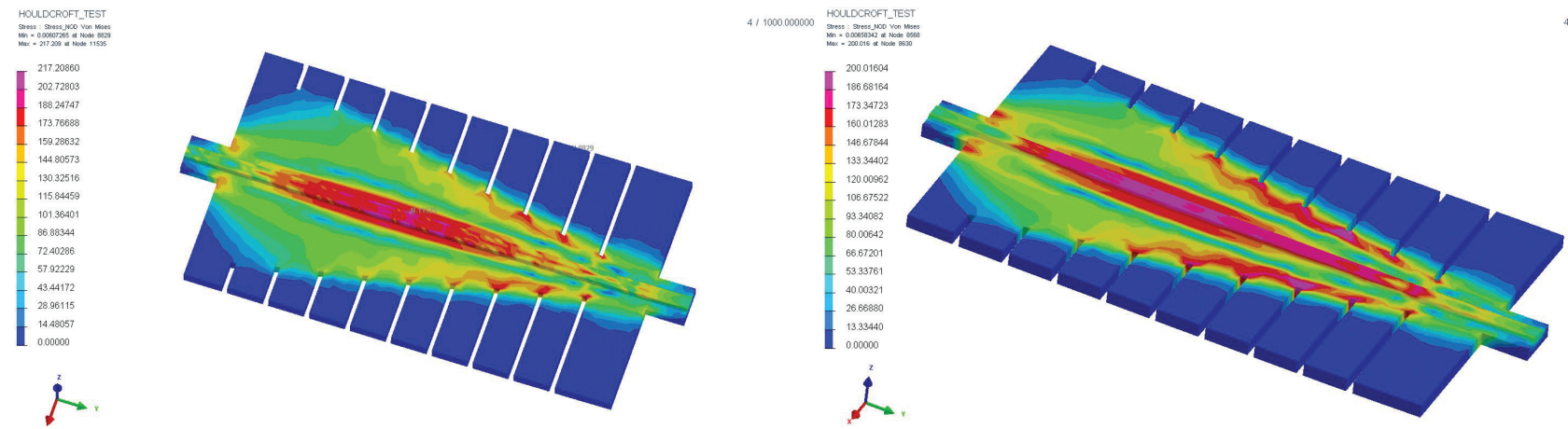

Rys. 6. Rozkład naprężeń zredukowanych (von Mises) po spawaniu i ochłodzeniu do temperatury otoczenia - po lewej wariant 1 (320 J/mm) po prawej wariant $2(400 \mathrm{~J} / \mathrm{mm})$

Fig. 6. Reduced stresses distribution (von Mises) after welding and cooling to the ambient temperature - on the left variant $1(320 \mathrm{~J} / \mathrm{mm})$ on the right variant $2(400 \mathrm{~J} / \mathrm{mm})$
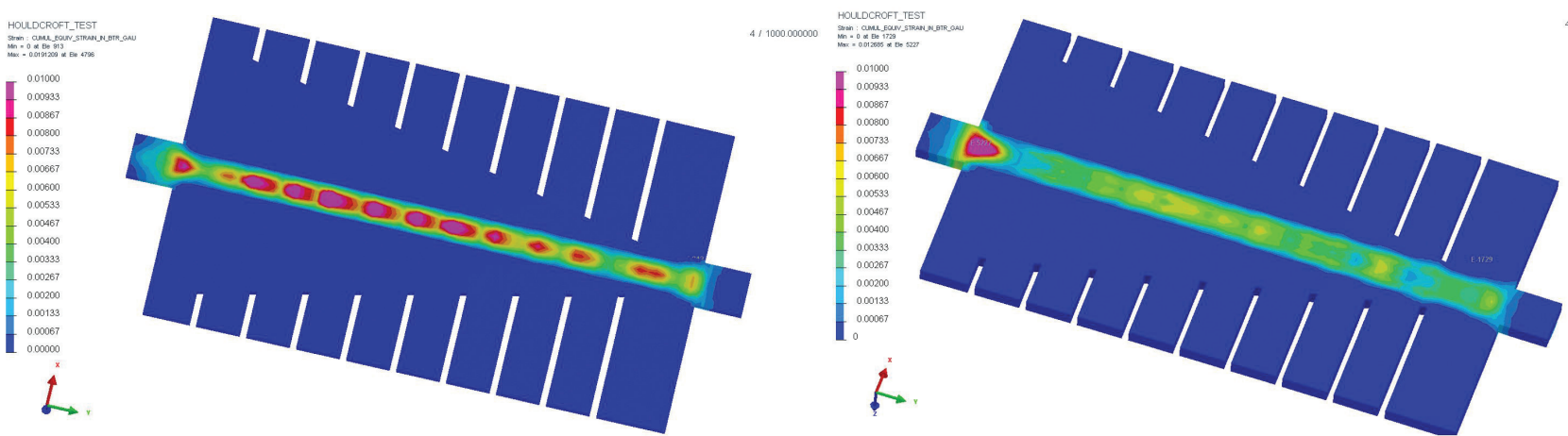

Rys. 7. Rozkład odkształceń plastycznych w obszarze BTR po spawaniu o ochłodzeniu do temperatury otoczenia - po lewej wariant 1 $(320 \mathrm{~J} / \mathrm{mm})$ po prawej wariant $2(400 \mathrm{~J} / \mathrm{mm})$ - widok od spodu próbki

Fig. 7. Plastic strains distribution in BTR area after welding and cooling to the ambient temperature - on the left variant $1(320 \mathrm{~J} / \mathrm{mm})$ on the right variant $2(400 \mathrm{~J} / \mathrm{mm})$ - view from the bottom of the specimen
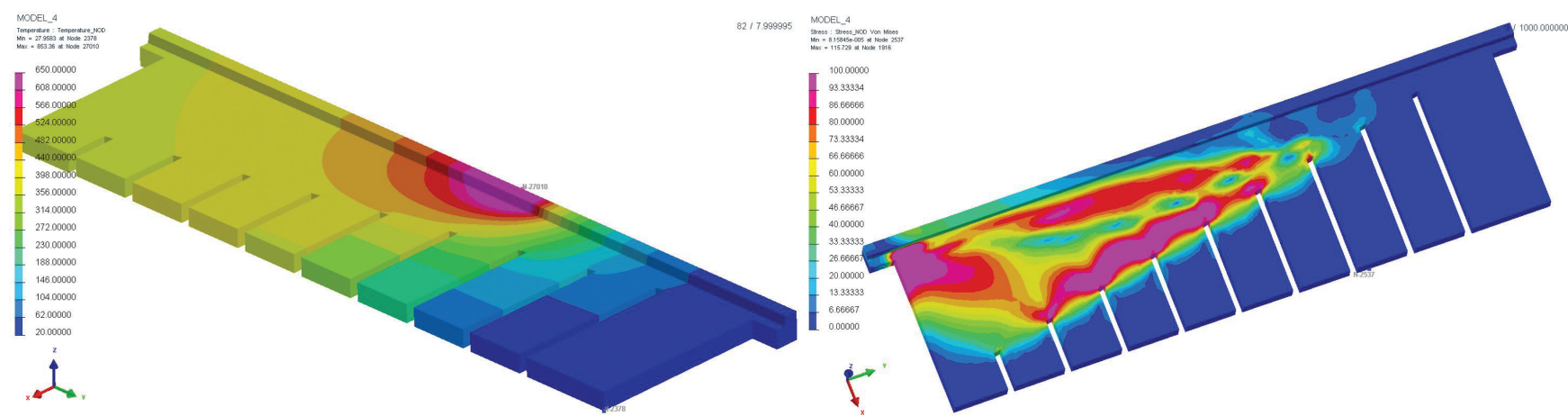

Rys. 8. Rozkład pola temperatury w trakcie spawania (po lewej) oraz naprężeń zredukowanych (von Mises) po spawaniu i ochłodzeniu do temperatury otoczenia (po prawej)

Fig. 8. Temperature fields distribution during welding (on the left) and reduced stresses distribution (von Mises) after welding and cooling to the ambient temperature (on the right) 
Wynika to głównie ze względu na znacznie mniejsze rozmiary próbki. Natomiast analizując rozkład naprężeń oraz odkształceń plastycznych w obszarze BTR i porównując go z wykonanymi próbami spawania, należy stwierdzić zgodność z wynikami obliczeń (rys. 4 i 9).

Również w przypadku badań prowadzonych dla próbek z nadstopu niklu INCONEL 625 konieczne było przygotowanie nowego modelu obliczeniowego. Stworzono kilka wariantów modeli obliczeniowych, zarówno pełnych, jak i z wykorzystaniem warunku symetrii. Obszar BTR został w tym przypadku określony w zakresie pomiędzy $1250 \div 1350^{\circ} \mathrm{C}$.

Analizowane były dwa warianty ilości wprowadzonego ciepła: 300 (wariant 1) i 200 (wariant 2) $\mathrm{J} / \mathrm{mm}$. Podobnie jak w przypadku prób wykonywanych na stopach aluminium i w tym przypadku wartości obliczonych naprężeń są podobne, jednak ich rozkłady w pewnym stopniu się różnią, (rys. 10).

Rozkład odkształceń plastycznych w obszarze BTR w przypadku wariantu $1(300 \mathrm{~J} / \mathrm{mm})$ wynosi $2,5 \%$ a w przypadku wariantu $2(200 \mathrm{~J} / \mathrm{mm})$ ok. 3,3\% (rys. 11). Obie maksymalne wartości występują na początku próbki - w miejscu gdzie dochodzi do inicjacji pęknięcia. Można również stwierdzić, że maksymalna wartość predykowanej wielkości odkształcenia plastycznego w obszarze BTR jest wysoka i może sygnalizować powstawanie pęknieć gorących, co zostało potwierdzone rzeczywistymi próbami.
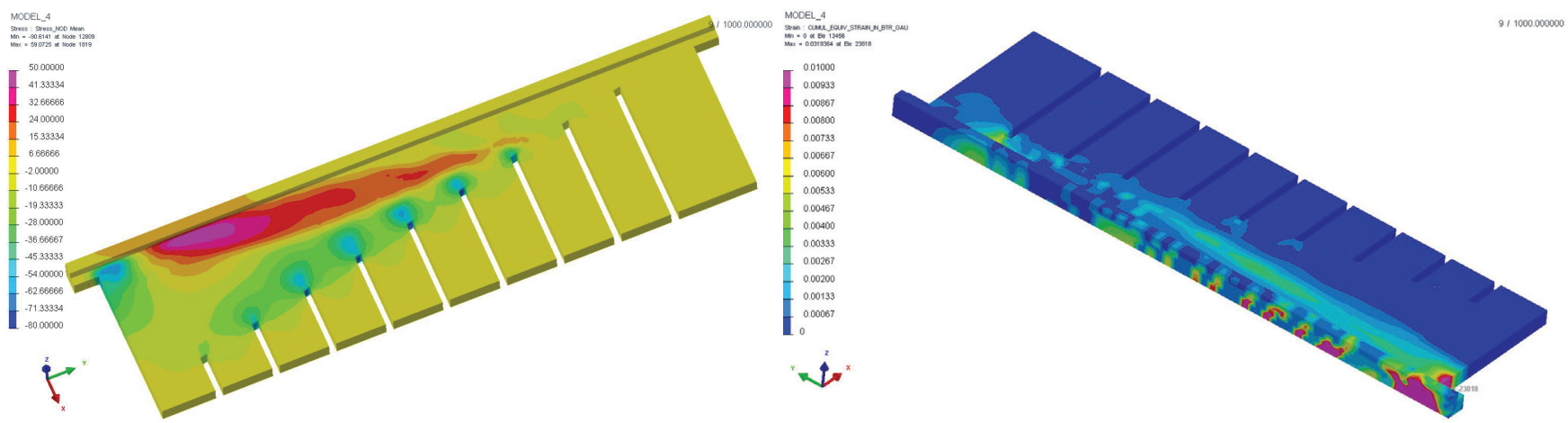

Rys. 9. Rozkład średnich napreżęń hydrostatycznych (po lewej) oraz rozkład odkształceń plastycznych w obszarze BTR po spawaniu i ochłodzeniu do temperatury otoczenia (po prawej)

Fig. 9. Mean stresses distribution (on the left) and plastic strains distribution in BTR area after welding and cooling to the ambient temperature (on the right)
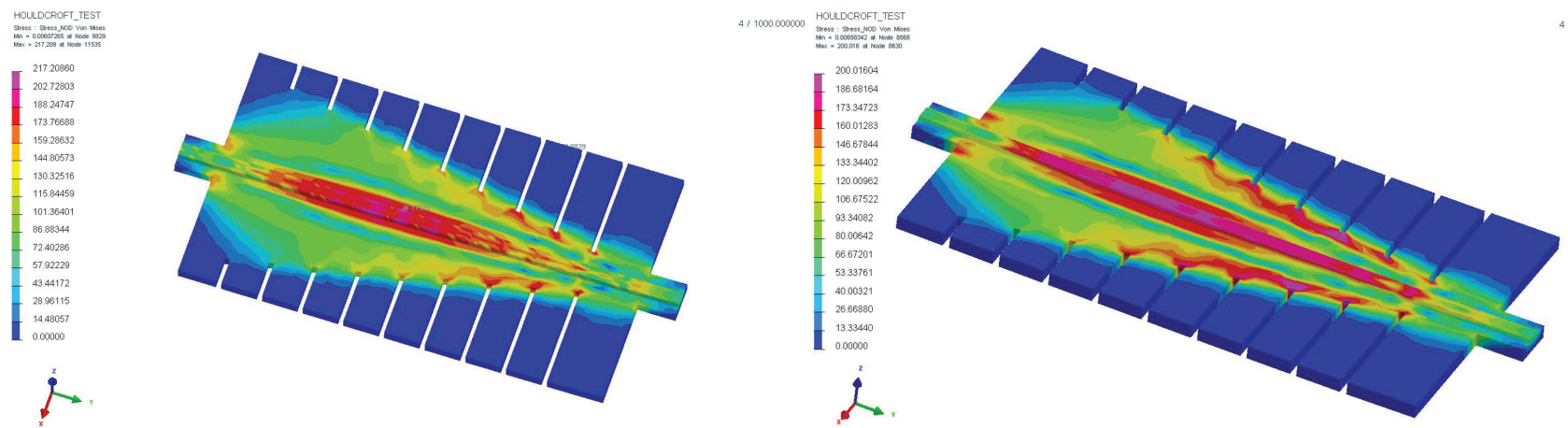

Rys. 10. Rozkład napręzeń zredukowanych (von Mises) po spawaniu i ochłodzeniu do temperatury otoczenia - po lewej wariant 1 (300 J/mm) po prawej wariant $2(200 \mathrm{~J} / \mathrm{mm})$

Fig. 10. Reduced stresses distribution (von Mises) after welding and cooling to the ambient temperature - on the left variant $1(300 \mathrm{~J} / \mathrm{mm})$ on the right variant $2(200 \mathrm{~J} / \mathrm{mm})$
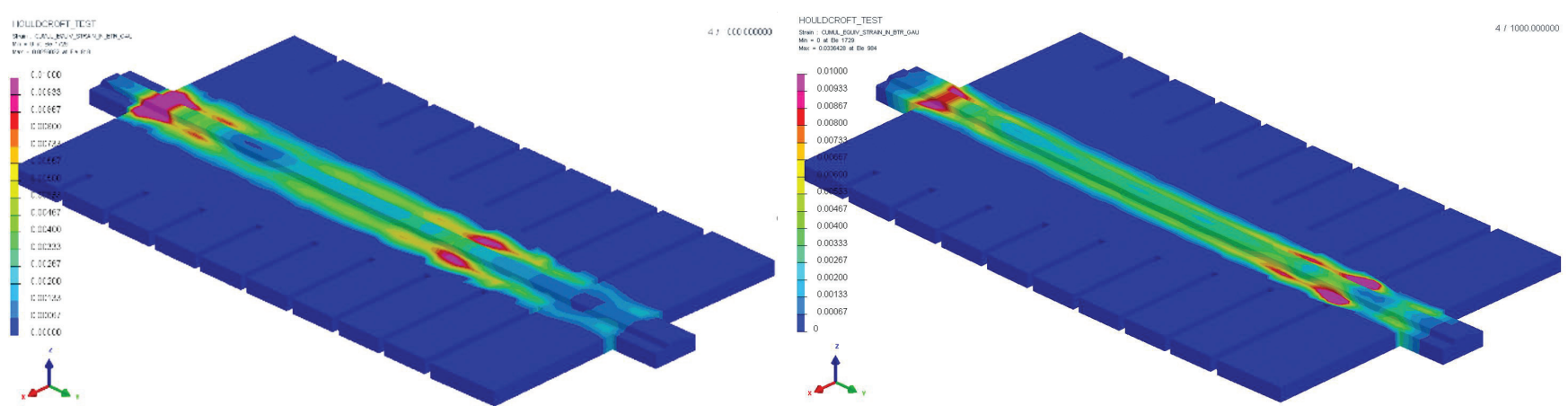

Rys. 11. Rozkład odkształceń plastycznych w obszarze BTR po spawaniu o ochłodzeniu do temperatury otoczenia - po lewej wariant 1 $(300 \mathrm{~J} / \mathrm{mm})$ po prawej wariant $2(200 \mathrm{~J} / \mathrm{mm})$

Fig. 11. Plastic strains distribution in BTR area after welding and cooling to the ambient temperature - on the left variant $1(300 \mathrm{~J} / \mathrm{mm})$ on the right variant $2(200 \mathrm{~J} / \mathrm{mm})$ 


\section{Podsumowanie}

W rozwoju metod obliczeniowych skłonności do pękania kruchego opracowany został model bazujący na określaniu pęknięć gorących, które powstają w zakresie temperatur kruchości tzw. Brittle Temperature Range (BTR). Analiza ta jest oparta na predykcji odkształceń, a następnie naprężeń szczątkowych. Odkształcenia powstają w wyniku pojawienia się pola temperatur wywołanego procesem spawania, co pozwala następnie określić prawdopodobieństwo wystąpienia wady na podstawie analizy rozkładu odkształceń plastycznych i/lub naprężeń szczątkowych. Niestety na obecną chwilę nie jest możliwe uwzględnienie wpływu składu chemicznego w modelach numerycznych. Na podstawie tych założeń przeprowadzono próby spawania potwierdzone wynikami analiz numerycznych. Przeprowadzone rzeczywiste próby spawania wykazały powstawanie pęknięć gorący w trakcie przetapiania metodą TIG próbek ze stopu aluminium AW6082 oraz nadstopu INCONEL 625 praktycznie w całym zakresie zastosowanych parametrów. Przeprowadzone analizy numeryczne zdają się potwierdzać wyniki testów, zatem proponowany model obliczeniowy jest poprawny, nawet jeżeli wymaga dalszej kalibracji oraz wprowadzania na bieżąco pewnych poprawek. W celu ułatwienia określania miejsc powstawania potencjalnych miejsc pękania gorącego, określony został specjalny parametr "cumulative equivalent strain in BTR", który można określić jako deformację plastyczną w obszarze temperaturowego zakresu kruchości i może on stanowić parametr służący określaniu skłonności do powstawania tego rodzaju pęknięć. Dalsze prace będą się skupiać na rozszerzaniu bazy wyników dostępnych z eksperymentów oraz kalibracji modelu obliczeniowego, a także opracowaniu kompletnej metodyki prowadzenia analiz numerycznych związanych z zagadnieniami pękania gorącego.

\section{Literatura}

[1] Kolarik L., Kovanda K., Valova M., Vondrous P., Dunovsky J.: Weldability test of precipitation hardenable aluminium alloy EN AW 6082 T6, MM Science Journal, July, 2011, pp. 242-247.

[2] Welding simulation user guide, Sysweld manual ESI Group, 2016.

[3] Slováček M., Kik T.: Wykorzystanie analiz numerycznych procesów spawania jako wsparcia technicznego w przemyśle. Cz. 1, Wstęp do zagadnienia symulacji numerycznych procesów spawania, Biuletyn Instytutu Spawalnictwa 2015 R. $59 \mathrm{nr}$ 4, s. 42-47.

[4] Slováček M., Vaněk M., Kik T.: Wykorzystanie analiz numerycznych procesów spawania jako wsparcia technicznego w przemyśle. Cz. 2, Metodologia i walidacja, Biuletyn Instytutu Spawalnictwa, 2015 R. 59 nr 5, s. 38-43.

[5] Kik T., Slováček M., Moravec J., Vaněk M.: Numerical Analysis of Residual Stresses and Distortions in Aluminium Alloy Welded Joints, Applied Mechanics and Materials, Vols. 809-810, 443-448 DOI: 10.4028/www.scientific.net/AMM.809-810.443
[6] Neumann H., Moravec J. : Trhliny za tepla ve svarových spojích, Zpráva TU Liberec, TUL-Z-17 HT- 01, prosinec 2017.

[7] Turowska A., Adamiec, J.: Zakres kruchości wysokotemperaturowej złączy spawanych stopu Inconel 625, Przegląd Spawalnictwa, 2015, R. 87, nr 10, s. 104-107.

[8] Lippold J.C.: Welding Metallurgy and Weldability. Copyright () 2015 by John Wiley \& Sons, Inc. All rights reserved Published by John Wiley \& Sons, Inc., Hoboken, New Jersey, Published simultaneously in Canada.

[9] Kolarik, L. et al.: Solidification cracking T-joint weldability test of precipitation hardenable Al alloys, Annals of DAAAM 2011, Vienna: DAAAM International, 2011. 